\title{
Do Cities and Counties Attempt to Circumvent Changes in their Autonomy by Creating Special Districts?*
}

\author{
Christopher B. Goodman ${ }^{\dagger}$ University of Nebraska at Omaha \\ Suzanne M. Leland University of North Carolina at Charlotte
}

This study uses forty years of data from the US Census of Governments to examine the impact of changes in local autonomy on the creation of the fastest growing form of local governments, special districts. Using fixed effects regression specified at the urban county and metropolitan statistical area level, we find that restrictions of fiscal autonomy of cities is associated with creation of new special districts. When the limits on fiscal autonomy interacts with grants of functional autonomy, amplification occurs. We find no analogous effects for county governments. These two findings are consistent with the circumvention argument made in the local autonomy literature.

Keywords: Special districts, home rule, tax and expenditure limitations (TEL), local governments

\section{Introduction}

For more than a half century, the growth in special districts in the United States has far outpaced the growth of other forms of local governments, and as of 2012 they now represent forty percent of all U.S jurisdictions (Berman and West 2012; U.S. Census Bureau 2013). The number of special districts in the United States has more than doubled since 1952 while other forms of local government have grown slightly (cities, towns), stayed constant (counties), or declined (school districts). While the rate of growth has waned somewhat in the recent years, special districts are an integral part of service delivery system of local areas. When compared to cities and counties, scholars know little about special districts despite their proliferation. This is an important question in public administration because special districts are more likely to be governed by appointed boards as opposed to elected officials (Stephens and Wikstrom 1998), and therefore may be subject to more business-like value of efficiency versus traditional public administration values that also include equity, accountability, and effectiveness, which all shape service delivery decisions.

The transition from public services provided by general purpose governments to services provided by specialized local governments also typically produces more fragmentation but may also provide a solution to meeting citizen's needs for services that a general purpose government is unable to provide due to the fiscal environment (Bollens 1986). Understanding the antecedents of such a trend and how these different components interact with various aspects of local government autonomy (such as home rule) is an important step forward in the study of local public economies and local government service delivery. One potential driver of the proliferation of special districts is the increasingly constrained fiscal environment in which general purpose local governments operate. Numerous scholars suggest it is possible that cities and counties utilize spe-

${ }^{*}$ Forthcoming at the American Review of Public Administration.

${ }^{\dagger}$ August 19, 2018 
cial districts to circumvent state-imposed restrictions on their activities (Sbragia 1996; Carr 2006; Farmer 2010; Carr and Farmer 2011) but there is little evidence of the costs and benefits of having a more businesslike approach.

This analysis examines the relationship between the limitations of city and county government fiscal autonomy (i.e. tax and expenditure limitations (TELs)) and the creation of special districts. Using forty years (nine periods) of data covering a time when taxpayer revolts led to many states and local governments to adopt tax expenditure limitations, we employ a model of urban special district creation at the county and metropolitan statistical area (MSA). We hypothesize that special district creation is likely positively correlated with the imposition of tax and expenditure limitations and there may be an interactive relationship between such limitations and functional autonomy (Farmer 2010). We offer three important contributions to the literature. First, our analysis explicitly focuses on special district creation (i.e. the number of new special districts in an area) over a long period rather than special district usage (i.e. the total number of special districts in an area). Second, the long panel nature of our data allows for more robust test of causal effects than previous literature. Much of the previous literature focuses on a limited time frame for their analysis ${ }^{1}$ and this makes the observation of change in local autonomy difficult (Goodman, Forthcoming). Finally, we focus on sub-state levels of aggregation. Individually, none of these contributions is novel. However, the combination of the three is unique in the literature and speaks directly to the role of local autonomy and the incentive structures such grants of powers create.

This analysis proceeds by examining the theoretical and empirical evidence on the creation of special districts. Next, we outline the hypotheses, data, and estimation strategy. Four models are calculated utilizing fixed effects regression. Our forty years of panel data demonstrate that state limitations of the fiscal autonomy of cities is associated with the creation of new special districts. When interacted with functional autonomy the effects are even greater. Interestingly, we find no analogous effects for county governments.

\section{Institutional Context of Special Districts}

Special districts are autonomous governments and, in most cases, provide a single or limited set of public services (Foster 1997; Goodman and Leland 2012). State-level institutions both grant and restrict local powers, but this power can vary substantially from one state to the next (Parks and Oakerson 1989). Authority varies based on state law (McCabe 2000, 121). Special districts often have the power to tax, issue debt, set its territorial boundaries, and deliver public services as determined by its state code (Parks and Oakerson 1989; McCabe 2000). The creation of special districts comes from cities and counties or state governments depending on the region, although McCabe (2000) argues that states generally do not create new special district governments. Rather, they develop rules that create incentives or disincentives for citizens and local governments to create special districts on their own.

The importance of special districts to the local public sector in the United States is often understated. As of 2012, special districts compose 42.5 percent of all local governments, making

\footnotetext{
${ }^{1}$ Carr (2006) focuses on a 10-year period from 1992 to 2002, Farmer (2010) focuses on a 5 year period between 2002 and 2007, and Carr and Farmer (2011) focus solely on 2002 data.
} 
this form of government the largest single type of local government. ${ }^{2}$ Additionally, the growth in special districts has dwarfed that of other forms of government. Since 1952, special districts have grown approximately 210 percent with an average annual growth rate of 1.9 percent. Over the same period, general purpose local governments grew only 5.5 percent with an average annual growth rate of 0.09 percent. While special districts demonstrate tremendous growth over time, their revenues and expenditures are only approximately 12 percent of those of local governments. Special districts do have about 26 percent of all outstanding local debt.

The most comprehensive data on special districts in the United States comes from the Census Bureau's Census of Governments. While many scholars note the potential poor quality of these data, ${ }^{3}$ we employ the only nationally representative data on special districts that is consistent across states and across time (Foster 1997). The Census Bureau defines as special district as an "independent, special purpose governmental units that exist as separate entities with substantial administrative and fiscal independence from general purpose local governments" (U.S. Census Bureau 2013, ix). A special district has fiscal independence when it can (1) determine its own budget without review from another government entity, (2) determine its own level of taxation, (3) determine and charge user fees, or (4) issue debt without review from another government entity. Administrative independence requires that a special district has either a popularly elected board, governing body representing two or more state or local governments, or an appointed board that is substantially different from the creating government. Independence is violated when another governmental entity controls the board or budget of a special district leading these organizations to be classified as "dependent" (Bollens 1957; Foster 1997). Due to this independence, scholars such as Burns (1994), Sbragia (1996), Stephens and Wikstrom (1998) have criticized special districts accountability in a representative democracy. In addition, as Frederickson (1999) characterizes the fragmentation they create as increasing "the silo or policy autonomy characteristics of government" (4).

Another feature of special districts is their territorial flexibility (Bollens 1957). Rather than having borders that abut, special districts have flexibility in their boundaries including overlapping other local governments. A near infinite combination of spatial arrangements of special districts is possible. Additionally, the number of special districts providing public services to a home can change over short distances. It is possible that next door neighbors face two different collections of public services provided. In addition to territorial flexibility, special districts enjoy considerable freedom from state laws governing the creation of other kinds of local governments. Special districts are not usually subject to minimum assessed value, population, or territorial size requirements that are imposed on cities or towns (Bollens 1957). Free of this restriction, special districts can cover nearly any land area regardless of the population being served.

\section{Review of the Literature}

Much of the theoretical understanding of the creation of local governments and individual citizen preferences begins with Tiebout's 1956 public choice theory. Burns (1994) builds on his political economy argument and suggests that citizens and businesses seek to create local governments

\footnotetext{
${ }^{2}$ The remaining percentages are as follows: counties, 3.4 percent; cities, 21.67 percent; towns or townships, 18.16 percent; and independent school districts, 14.3 percent. Business Improvement Districts are not included since they are quasi-public entities.

${ }^{3}$ See Leigland (1990) for an introduction.
} 
to access the powers associated with them. For general purpose governments, this is largely the power to exclude individuals from a community through zoning. For special districts, this is generally for the power to provide services, eminent domain, and occasionally lower taxation. Local actors may seek to circumvent state limitations on autonomy by creating special districts to continue to provide public services (Bunch 1991; Sbragia 1996). Carr and Farmer (2011) note that this tradition presumes that citizens prefer general purpose local governments over special districts when possible. Foster (1997) explains that three primary groups are involved in the creation of special districts. Each must accept that the benefits of specialized governments outweigh the costs, and, in each instance, the associated costs and benefits differ. For local residents who are the consumers of public goods and services provided, the associated benefits of specialized governments (functional specialization and territorial flexibility) outweigh the potential loss of "political visibility, accountability, and responsiveness" (Foster 1997, 101). For local government officials, the benefits associated with the distinctive nature of special districts must outweigh the loss of control and coordinating costs. Finally, private developers almost always prefer special districts because they are susceptible to "capture" via the appointment of officials (Foster 1997). However, developers will also prefer general purpose local governments when such governments are friendly to development or when broad land use controls afforded to general purpose local governments are essential for generating economic. Developers also see special districts as an alternative to impact fees because they do not readily allow for bonds to be issued to finance construction and the costs are not just covered by new residents (National Association of Home Builders 2014). Another set of literature explores why states grant or restrict the freedom of action to general purpose governments because of their past history, citizen initiatives/referendum, or a crisis (Parks and Oakerson 1989). We extend this research by focusing on three variants of autonomy. Tax and expenditure limits impose restrictions on the taxing and spending powers of local governments. Debt limitations restrict the ability of local government to access the debt market. Moreover, the granting of functional home rule powers increases the power of local governments to chart their own destiny in terms of service delivery.

The consensus is that the modern movement to limit the taxing and spending powers of local governments began with Proposition 13 in California in 1978. However, states have been imposing limitations on the taxing and spending powers of local governments for much longer (Sokolow 1998). It is common to classify tax and expenditure limitations as to their ability to bind the behavior of local governments (Joyce and Mullins 1991). Non-binding TELs are easily circumvented by the target government. Potentially binding TELs are much more difficult to evade. These types of TELs are usually a collection of non-binding TELs, whose combined effect constrains behavior. Prior to 1970, only a handful of states imposed tax and expenditure limitations on local governments that had the potential to influence the behavior of local governments (Shadbegian 1998). ${ }^{4}$ After 1970, 27 additional states imposed a potentially binding tax and expenditure limit on local governments within their boundaries.

Many states limit the debt issuing ability of local governments to minimize defaults and overborrowing which was typical of the late 1800s and early 1900s (Farnham 1985; Epple and Spatt 1986). In general, local debt limits come in two flavors. First, there are limits to the amount of debt a local government can accumulate. These types of limits are usually expressed as a percentage of assessed value or a millage rate equivalent for an individual local government. Typically, a

\footnotetext{
${ }^{4}$ Five states imposed a TEL on local governments: Arizona, Colorado, Oregon, Pennsylvania, and Utah. Utah eliminated its potentially binding TEL on local governments in 1986.
} 
supermajority of voters must approve any proposal to exceed the debt limits. In a few cases where there is not a vote, there are still very stringent state limitations on issuing debt. Second, before debt can be authorized, requirements are placed on local governments to obtain voter approval before debt can be authorized. These provisions can require only a simple majority of votes or can require some form of supermajority. Those limits requiring a supermajority are more stringent.

Finally, the actions of local governments may be limited. As opposed to Dillion's Rule, home rule outlines the actions of local governments that may be taken without express approval of the state (Krane, Rigos, and Hill 2001). The now defunct Advisory Commission on Intergovernmental Relations (1981) defines home rule to be composed of four dimensions: Structural, functional, finance, and personnel. Most recent research utilizes only the first three dimensions. First, structural home rule outlines the powers that citizens possess, such as creating new local governments and the rules that govern the actions of local governments in the areas of annexation and charters. Second, functional home rule outlines the powers of local governments around service provision. As Krane, Rigos, and Hill (2001) note, the number of functions local governments engage in has increased over time and they find little evidence of a "division of labor" between municipalities and counties. Both cities and counties provide an ever-increasing number of public service within the boundaries set by the functional home rule granted by their state. Finally, fiscal home rule deals with discretion of local government with respect to the choice of expenditures and revenues. Fundamentally, many of the issues raised with fiscal home rule are covered with TELs and local debt limits outlined above. Together, these three aspects of home rule are the degree of autonomy provided to local governments in a state. We choose to focus on the latter two forms of limits on autonomy, functional and fiscal, because structural home rule does not empirically vary much in our data over time and is subsumed by our treatment of time invariant effects in our modeling technique.

The academic literature has attempted to link various facets of local autonomy to the creation and usage of special districts with a wide range of methods, levels of aggregation, and findings. Overall, this literature suggests there is no agreed upon effects of limitations of local autonomy and special district creation. Positive, negative, and null results can all be found in the literature.

MacManus (1981) is among the first to demonstrate a circumvention-like or positive finding between tax and expenditure limits and special district creation. She finds a positive correlation between TELs and property taxing special districts among standard metropolitan statistical areas in the southern region of the US. Among the first regression based analyses, Nelson (1990) finds a similar positive result with TELs leading to the creation of special districts. McCabe (2000) echoes Nelson's findings. The remaining positive findings are contingent findings with the effect of TELs interacted with some other variable. Bowler and Donovan (2004) find a positive relationship between TELs and special districts, contingent on the ease of using citizen initiatives. Carr (2006) finds a positive relationship between TELs imposed on cities, contingent on county TELs, and Carr and Farmer (2011) find the opposite with a positive relationship for county TELs (contingent relationship with municipals TELs is overall negative). This is like the findings of Farmer (2010) where the unconditional relationship between TELs and creation is positive, but the relationship conditional on functional home rule is overall negative. Bauroth (2015) and Foster (1997) find negative relationships between property tax limits and special district creation. Finally, Berry (2009), Billings and Carroll (2012), Lewis (2000), and Shi (2017) find no relationship between TELs and special districts. 
The seminal empirical analysis of debt limits and special district creation is Bunch (1991)). Bunch finds a positive relationship between constitutional debt limits and the usage of state-level public authorities. Several other analyses demonstrate similar findings at the local level (Foster 1997; McCabe 2000). However, Nelson (1990), Frant (1997), and Shi (2017) find no relationship between the two. Generally, increased functional home rule powers, broadly defined, are associated with a reduction in the number of special districts created. McCabe (2000) and Farmer (2010) find this negative relationship; however, Bauroth (2015) finds a positive relationship between municipal home rule powers and special district creation. Nelson (1990), Carr (2006), and Shi (2017) find no relationship.

There is much evidence to suggest a relationship between local autonomy and special districts; however, the exact relationship is not agreed upon in the literature. Moreover, the more recent literature suggests some form of a contingent relationship is important in our understanding of the relationship between reductions of local autonomy and the creation of special districts (Bowler and Donovan 2004; Carr 2006; Carr and Farmer 2011; Farmer 2010). We will outline our hypotheses, data generation, estimation strategy in the next section.

\section{Hypotheses, Data \& Estimation Strategy}

\section{Hypotheses}

Following Carr and Farmer (2011), we assume residents and businesses prefer to receive services from general purpose governments and will turn to special districts to satisfy their demands for services if general purpose government cannot do so. This assumption leads to a circumvention argument where, if limited in their ability to provide public services, general purpose governments, citizens, businesses, or a combination of the three will seek to evade such limits by creating special districts to provide demanded services. Furthermore, following Farmer (2010), we posit a conditional relationship between fiscal autonomy, specifically tax and expenditure limits, and functional autonomy. Farmer (2010) hypothesizes that the same underlying rationale for circumvention, the desire to access services, is the same for both fiscal and functional autonomy; therefore, their combination should amplify the effect. Our estimation technique allows us to take this hypothesis one step further (see below). We expect that for areas with existing functional home rule powers, the imposition of a potentially binding TEL will amplify the circumvention effect. Because of our ability to control for time invariant effects such as other forms of autonomy or state laws, we can parse this hypothesis in a more rigorous manner than previous literature.

Overall, we hypothesize that any reduction in local autonomy will lead to the creation of new special districts; however, we do not necessarily assume that this effect will be the same for cities and counties. In particular, counties occupy a rather unique position in American federalism both trending toward providing more urban-like services (Krane, Rigos, and Hill 2001) and also being the provider of last resort for a number of local services (Farmer 2010). This relationship is an artifact of the role of counties in the local intergovernmental landscape as an arm of the state. That is state law determines how and what counties do (Benton 2002b; Menzel et al. 1992). Unlike most cities, counties were created without the consent of voters with little or no charter or legislative powers and shared immunity with the state. They are charged with property assessment and record keeping. Most have also emerged as providers of hospitals, public welfare, education and corrections for state governments. Urban counties are likely to provide transportation and environmental planning (Benton 2002b). Therefore, county governments are less likely to be in 
control of their budgetary expenditures because of unfunded mandates from the state. They are more dependent upon external revenue than cities (Benton 2002b; Menzel et al. 1992). At the same time, counties, particularly urban counties, face pressure to expand services because increased demand, increased trust from citizens, and urbanization (Benton 2002a). For these reasons cities and counties may respond differently to the limitation of fiscal or functional autonomy.

\section{Data}

Nationally representative data on the creation of special districts is elusive. Currently, only the Census of Governments provides the necessary data to conduct this analysis. While this data source is deficient in many ways, lacking even basic information on population or land area served, the Census Bureau provides information on functional policy area and contact information for special districts for each Census of Government conducted. According to the Census Bureau, significant effort is expended in tracking down newly created special district and those that have been eliminated through consolidations or destructions. Using this imperfect exercise as a base, we calculate the number of new special districts in a county in each year. The focus on newly created districts, aggregated at the county, over a long period of time is novel approach in the literature. $^{5}$

The data for fiscal limitations and home rule ultimately emanates from the Advisory Commission on Intergovernmental Relations (ACIR). Turning to TELs first, Advisory Commission on Intergovernmental Relations (1995) and the work of Joyce and Mullins (1991), Mullins and Joyce (1996), and Mullins and Wallin (2004) forms the basis of our measurement of the presence and potential influence of TELs. First explained in Joyce and Mullins (1991) and expanded in Mullins and Wallin (2004), TELs come in seven varieties: overall property tax rate restrictions (applied to all governments), specific property tax rate restrictions (applied to specific types of local governments), property tax levy limits, general revenue increase limits, general expenditure increase limits, limits on assessment increases, and truth in taxation (full disclosure) requirements. The impact of each varies as to the extent that they bind the behavior of the target government. Joyce and Mullins (1991) and their later works adopt the language of non-binding and potentially binding to categorize individual TELs. Non-binding TELs are easily circumvented by the target government. Potentially binding TELs are much more difficult to evade. These types of TELs are usually a collection of non-binding TELs, whose combined effect constrains behavior. The latter type is of interest to this analysis because we are interested in TELs that restrict the behavior of general purpose governments to provide demanded services. A potentially binding TEL is indicated if the state imposes any of the following TELs or combinations of TELs: an overall or specific rate limit coupled with an assessment limit; a property tax levy limit; a general revenue or expenditure increase limit. Potentially binding TELs can be imposed on counties or cities or both.

Local debt limits are derived from the Advisory Commission on Intergovernmental Relations (1993). This study updates qualitative data on state-imposed debt limits on local government conducted in 1978. The following information is collected: the presence of a local debt limit, whether the limit is expressed as a percentage of assessed value or some other way, whether there are referendum requirements, which kinds of debt referendum requirements apply to, and whether a super majority is required for passage. The authors have built upon the Advisory Commission

\footnotetext{
${ }^{5}$ Bauroth (2015), Carr and Farmer (2011), and Farmer (2010) focus on the county as a unit of aggregation; Bauroth (2015), Billings and Carroll (2012), Farmer (2010), and McCabe (2000) focus on special district creation (rather than usage); and Shi (2017) focuses on a long-time. None do the combination of the three.
} 
on Intergovernmental Relations (1993) data to create a panel dataset of local debt limitations from 1900 to 2012 . $^{6}$ We utilize limits that are a function of assessed value or millage rate as our measure of debt limits as these provide a concrete restriction of debt issuance. Information on home rule powers is derived from Advisory Commission on Intergovernmental Relations (1993) and Krane, Rigos, and Hill (2001). While home rule powers vary significantly from state to state, Krane, Rigos, and Hill (2001) classify each state as granting structural, functional, and fiscal home rule or not as well as a date of enactment. We utilize these data to construct our functional home rule data.

To test the unconditional hypothesis outlined above, a model built upon recent research (Nelson 1990; Carr and Farmer 2011; Billings and Carroll 2012; Goodman and Leland 2012; Goodman, Forthcoming) is specified.

$$
\begin{aligned}
G_{i t}=\alpha & +\delta_{1} T E L_{j t, m}+\delta_{2} \text { DLIM }_{j t, m}+\delta_{3} F_{H M} M_{j t, m} \\
& +\rho_{1} T E L_{j t, c}+\rho_{2} D_{L I M_{j t, m}}+\rho_{3} F H M_{j t, m} \\
& +\beta \boldsymbol{X}_{i t}+\phi_{j}+\tau_{t}+\varepsilon_{i t}
\end{aligned}
$$

Where $G_{i t}$ is the number of new special districts in county area $i$ in time $t, T E L_{j t}$ is a binary variable indicating the presence of a potentially binding TEL on cities $(m)$ or counties $(c)$ in state $j$ in time $t, D L I M_{j t}$ is a binary variable indicating the presence of a debt limit on cities $(m)$ or counties $(c)$ in state $j$ in time $t$, and $F H M_{j t}$ is a binary variable indicating the presence of functional home rule powers for cities $(m)$ or counties $(c)$ in state $j$ in time $t$. A vector of control variables $\left(\boldsymbol{X}_{i t}\right)$ is included as well as time-invariant state fixed effects $\left(\phi_{j}\right)$ and year fixed effects $\left(\tau_{t}\right)$.

The following equation is specified to test the conditional hypothesis outlined above.

$$
\begin{aligned}
G_{i t}=\alpha & +\delta_{1} T E L_{j t, m}+\delta_{2} D_{L I M_{j t, m}}+\delta_{3} F H M_{j t, m}+\delta_{4}\left(T E L_{j t, m} \times F H M_{j t, m}\right) \\
& +\rho_{1} T E L_{j t, c}+\rho_{2} D L I M_{j t, m}+\rho_{3} F H M_{j t, m}+\rho_{4}\left(T E L_{j t, c} \times F H M_{j t, c}\right) \\
& +\beta X_{i t}+\phi_{j}+\tau_{t}+\varepsilon_{i t}
\end{aligned}
$$

Equation 2 is identical to equation 1 except for the addition of an interaction term $T E L_{j t} \times F H M_{j t}$ for both cities and counties.

The literature identifies several factors that may influence the creation of special districts. Environmental or economic factors have been influential in the explaining the variation. For this reason, three such variables are utilized: per capita personal income, population, and jobs per capita form our measurement of environmental factors (Goodman, Forthcoming). In addition to these demand-oriented variables, variations in preferences have been suggested as important drivers of the number of special districts in an area (Nelson 1990). Therefore, the variation in age and race are included. Following the literature (Martinez-Vasquez, Rider, and Walker 1997; Fisher and Wassmer 1998), these two variables are constructed using a Leik (1966) index. Larger values of these variables are indicative of more variation of the age or race. In addition to preferences and the variation of preferences for special districts, an additional variable, the change in the number of cities in included. In the MSA specific models, two additional control variables, the number of counties in an MSA and land area in square miles are included to control for the physical size of the MSA.

This analysis primarily focuses on urban counties as the unit of analysis. ${ }^{7}$ We choose to focus on urban counties because urban special districts are much more likely to provide a wide variety

\footnotetext{
${ }^{6}$ These data are available at https:/ / github.com/cbgoodman/localdebtlimits/releases.

${ }^{7}$ We classify a county as urban if it is a member of an MSA in 1999.
} 
of public services whereas rural special districts are typically confined to natural resource management and fire services. Additionally, urban special districts are often in direct competition with urban general purpose governments. Rural special districts tend to be the sole provider of such services. The primary data for this analysis are derived from nine consecutive Census of Governments (COG) from 1972 to 2012. The census is conducted every five years. This results in data from 1972, 1977, 1982, 1987, 1992, 1997, 2002, 2007, and 2012. The remaining data in the dataset is derived from Regional Economic Information System (REIS) of the Bureau of Economic Analysis and the Surveillance, Epidemiology, and End Results (SEER) program at the National Cancer Institute. To allow for comparability over time, the local governments in Alaska and Hawaii have been dropped. This results in an unbalanced panel of 6,472 total observations over 814 county areas. Additionally, the data are aggregated to the MSA level. This results in an unbalanced panel of 2,255 observations over 284 MSA after dropping MSAs that cross state boundaries. ${ }^{8}$ See Table 1 for summary statistics for all variables employed in this analysis.

Table 1: Descriptive statistics

\begin{tabular}{|c|c|c|c|c|c|c|}
\hline \multirow[b]{2}{*}{ Variable } & \multirow[b]{2}{*}{ Source } & \multirow[b]{2}{*}{ Units } & \multicolumn{2}{|c|}{ Urban Counties } & \multicolumn{2}{|c|}{ MSAs } \\
\hline & & & Mean & St. Dev & Mean & St. Dev \\
\hline New special districts & COG & Count & 2.466 & 6.533 & 5.946 & 14.730 \\
\hline New special districts (IHS) & COG & $\log$ & 0.960 & 1.054 & 1.632 & 1.228 \\
\hline County TEL & Mullins & Indicator, 0 or 1 & 0.574 & 0.495 & 0.637 & 0.481 \\
\hline Municipal TEL & Mullins & Indicator, 0 or 1 & 0.538 & 0.499 & 0.600 & 0.490 \\
\hline County debt limit & ACIR & Indicator, 0 or 1 & 0.762 & 0.426 & 0.757 & 0.429 \\
\hline Municipal debt limit & ACIR & Indicator, 0 or 1 & 0.840 & 0.367 & 0.819 & 0.385 \\
\hline County functional home rule & Krane et al. & Indicator, 0 or 1 & 0.435 & 0.496 & 0.451 & 0.498 \\
\hline Municipal functional home rule & Krane et al. & Indicator, 0 or 1 & 0.747 & 0.435 & 0.753 & 0.431 \\
\hline Personal income, per capita & REIS & $\$ 1000$ per capita & 27.038 & 8.920 & 29.992 & 9.127 \\
\hline Population (1000s) & REIS & $1000 \mathrm{~s}$ & 248.226 & 529.868 & 610.851 & 1052.370 \\
\hline Jobs, per capita & REIS & Per capita & 0.398 & 0.137 & 0.444 & 0.092 \\
\hline Age Index & SEER & Index, 0 to 1 & 0.409 & 0.027 & 0.409 & 0.027 \\
\hline Race Index & SEER & Index, 0 to 1 & 0.151 & 0.130 & 0.171 & 0.114 \\
\hline Chg in Cities & COG & Count & 0.099 & 0.611 & 0.245 & 1.083 \\
\hline No. of Counties & COG & Count & - & - & 2.137 & 1.945 \\
\hline Land Area (sq. mi.) & COG & Square miles & - & - & 2075.324 & 3129.592 \\
\hline
\end{tabular}

$n=6,472$ (counties); $n=2,255$ (MSAs)

\section{Estimation Strategy}

Both equation 1 and 2 are estimated using OLS; however, the dependent variable presents some issues. The count of newly created special districts demonstrates a positive skew and the usual solution to such a problem is to transform the data using logs. As we observe the creation of new special districts rather than the usage of special districts, there are a non-trivial number of zeros in the data and this complicates the usage of log transformations. To overcome this issue, we transform our dependent variable using inverse hyperbolic sine transformation (Johnson 1949;

\footnotetext{
${ }^{8} \mathrm{~A}$ list of eliminated county areas and MSAs is available upon request.
} 
Burbridge, Magee, and Robb 1988; MacKinnon and Magee 1990).

$$
\operatorname{IHS}\left(G_{i t}\right)=\ln \left(G_{i t}+\sqrt{G_{i t}^{2}+1}\right)
$$

The inverse hyperbolic sine (IHS) is defined for positive, negative, and zero values. Additionally, it acts similarly to a natural logarithm and the interpretation is identical. The transformation enjoys wide support in the economics literature but is not commonly used by public administration scholars. The IHS transformation allows for estimation via OLS with all the benefits of a log transformation and incorporating zeros. As a robustness check, we also estimate equations 1 and 2 using negative binomial regression. All relevant information on this robustness procedure including an explanation of the estimation technique and results can be found in Appendix A. The results are qualitatively similar to the OLS results we present below.

State level fixed effects are included to control for any state specific, time-invariant effects that may be correlated with the error term. We make an implicit assumption that state-level fixed effects provide an adequate control for other institutional factors such as other forms of local autonomy (structural or administrative) as well as state-specific law surrounding the creation of special districts (Goodman and Leland 2012; Foster 1997). Year fixed effects are included to control for any effects that are shared by all urban counties or metropolitan areas. Lastly, since the primary variables of interest originate at the state level, the standard errors have been clustered on the state to correct for any shared correlation in the error term these policies may introduce.

\section{Results}

Table 2 shows results from four regressions where the dependent variable is the IHS transformation of newly created special districts. Models one and three present the unconditional results from equation 1 for counties (1) and MSAs (3). Models two and four present the conditional results, interacting TELs and functional home rule, from equation 2 for counties (2) and MSAs (4).

Turning first to unconditional regressions (models one and three), as hypothesized, the imposition of a TEL on municipal governments is associated with creation of new special districts. This only hold for both the county model (1) and the MSA model (3). The imposition of a potentially binding TEL on cities, holding all else constant, is associated with 22 to 38 percent more special districts. This provides evidence of the circumvention argument made above. Additionally, this is a large effect size compared to previous literature finding a positive relationship between TELs and the creation of special districts. There is no similar effect for potentially binding TELs imposed on county governments. The remainder of fiscal and functional autonomy variables in the unconditional models are not statistically different from zero. These results provide partial support for previous null findings in these areas (Goodman, Forthcoming; Carr 2006).

In order to test the conditional hypothesis, models two and four in table 2 estimate equation 2 with potentially binding TELs interacted with functional autonomy. As described above, one might expect that when a city or county with functional autonomy is subjected to a limitation of their fiscal autonomy, they will respond by choosing to create a special district to continue to provide services demanded by individuals and businesses. One must take care in interpreting the non-interacted coefficients from a multiplicative interaction (Braumoeller 2004; Brambor, Clark, and Golder 2006). For instance, the hypothesis test associated with the municipal TEL variable in table 2 is only applicable to circumstances when functional home rule is absent. The inverse 
Table 2: Fixed Effects Regression Results

\begin{tabular}{|c|c|c|c|c|}
\hline \multirow[b]{2}{*}{ Variable } & \multicolumn{2}{|c|}{ Urban Counties } & \multicolumn{2}{|c|}{ MSAs } \\
\hline & (1) & (2) & (3) & $(4)$ \\
\hline \multicolumn{5}{|l|}{ Fiscal $\mathcal{E}$ autonomy constraints } \\
\hline \multirow[t]{2}{*}{ Municipal TEL } & 0.3564 & -0.1950 & 0.4646 & -0.2609 \\
\hline & $(0.202)$ & $(0.284)$ & $(0.382)$ & $(0.483)$ \\
\hline \multirow[t]{2}{*}{ Municipal functional home rule } & $0.2235^{*}$ & -0.1575 & $0.3854^{* *}$ & -0.1663 \\
\hline & $(0.099)$ & $(0.144)$ & $(0.110)$ & $(0.227)$ \\
\hline Municipal TEL $x$ & - & $0.6825^{* *}$ & - & $0.8262^{* *}$ \\
\hline Municipal functional home rule & & $(0.159)$ & & $(0.227)$ \\
\hline \multirow[t]{2}{*}{ Municipal debt limit } & -0.2488 & -0.2296 & -0.4161 & -0.4193 \\
\hline & $(0.188)$ & $(0.210)$ & $(0.220)$ & $(0.237)$ \\
\hline \multirow[t]{2}{*}{ County TEL } & -0.1648 & -0.0429 & -0.0514 & 0.0077 \\
\hline & $(0.204)$ & $(0.277)$ & $(0.371)$ & $(0.463)$ \\
\hline \multirow[t]{2}{*}{ County functional home rule } & -0.0306 & 0.0198 & 0.1312 & 0.0939 \\
\hline & $(0.131)$ & $(0.178)$ & $(0.167)$ & $(0.202)$ \\
\hline County TEL $x$ & - & -0.1979 & - & -0.0757 \\
\hline County functional home rule & & $(0.198)$ & & $(0.231)$ \\
\hline \multirow[t]{2}{*}{ County debt limit } & 0.0567 & 0.0265 & -0.0435 & -0.0201 \\
\hline & $(0.081)$ & $(0.103)$ & $(0.202)$ & $(0.240)$ \\
\hline \multicolumn{5}{|l|}{ Controls } \\
\hline \multirow[t]{2}{*}{ Personal income, per capita } & $0.0086^{*}$ & $0.0085^{*}$ & $0.0271^{* *}$ & $0.0273^{* *}$ \\
\hline & $(0.004)$ & $(0.004)$ & $(0.008)$ & $(0.008)$ \\
\hline \multirow[t]{2}{*}{ Population (1000s) } & $0.0003^{* *}$ & $0.0003^{* *}$ & $0.0002^{* *}$ & $0.0002^{* *}$ \\
\hline & $(0.000)$ & $(0.000)$ & $(0.000)$ & $(0.000)$ \\
\hline \multirow[t]{2}{*}{ Jobs, per capita } & 0.3278 & 0.3327 & -0.3364 & -0.3455 \\
\hline & $(0.167)$ & $(0.167)$ & $(0.622)$ & $(0.617)$ \\
\hline \multirow[t]{2}{*}{ Age index } & -1.8283 & -1.8196 & 1.0477 & 1.1354 \\
\hline & $(1.250)$ & $(1.247)$ & $(1.472)$ & $(1.505)$ \\
\hline \multirow[t]{2}{*}{ Race index } & 0.1069 & 0.1037 & 0.2755 & 0.2882 \\
\hline & $(0.176)$ & $(0.178)$ & $(0.467)$ & $(0.455)$ \\
\hline \multirow[t]{2}{*}{ Chg. in cities } & $0.0748^{* *}$ & $0.0728^{* *}$ & 0.0495 & 0.0473 \\
\hline & $(0.024)$ & $(0.027)$ & $(0.035)$ & $(0.038)$ \\
\hline \multirow[t]{2}{*}{ No. of counties } & - & - & $0.1752^{* *}$ & $0.1754^{* *}$ \\
\hline & & & $(0.042)$ & $(0.042)$ \\
\hline \multirow[t]{2}{*}{ Land area (sq. mi.) } & - & - & $0.0001^{* *}$ & $0.0001^{* *}$ \\
\hline & & & $(0.000)$ & $(0.000)$ \\
\hline State FE & Yes & Yes & Yes & Yes \\
\hline Year FE & Yes & Yes & Yes & Yes \\
\hline Observations & 6,472 & 6,472 & 2,255 & 2,255 \\
\hline States & 47 & 47 & 47 & 47 \\
\hline
\end{tabular}


is also the case for functional home rule for cities. As such, the test of statistical significance on these coefficients is for a specific hypothesis test rather than a more general test in model one or three. We interpret the conditional results in the following way. First, a joint test of significance of all interacted variables (TEL, functional autonomy, and interaction) is conducted. For both model two and four, the municipal interaction is jointly significant; however, the results for the county interaction fail to reject the null hypothesis of a joint zero effect at any normal level of significance. From this initial step, we conclude there is no conditional relationship between fiscal autonomy and functional autonomy for county governments. ${ }^{9}$ This null result for county governments is in line with our unconditional findings; though, it is at odds with the findings of Farmer (2010) who finds a negative conditional relationship between functional autonomy and TELs when either influence is more restrictive.

Second, we proceed with an analysis of the predicted effects of the municipal interaction. Graphically, these can be seen in figure $1 \mathrm{a}$ for urban counties and figure $1 \mathrm{~b}$ for MSAs. In both figures, the left panel demonstrates the predicted effects of a potentially binding TEL on cities when functional autonomy is present. The right panel demonstrates the opposite with the predicted effects of functional autonomy when a potentially binding TEL is present. As can be seen, the effect of functional autonomy when a TEL is no present is statistically zero for both urban counties and MSAs. However, when an urban county or an MSA has functional autonomy and a potentially binding TEL is introduced, there is a statistically significant increase in the proportion of special districts created. Evaluated at the mean of urban counties, the imposition of a potentially binding TEL for municipalities when municipalities already have broad functional home rule power leads to an increase of 1.29 new special districts on average. The same effect for MSA is larger with an expected increase of 3.9 new special districts. This is unsurprising as MSA are typically a large geographic unit of analysis. When we examine the interaction from the opposite direction, a similar result occurs. In the presence of a TEL, the effect of functional autonomy is statistically zero; however, when functional autonomy is granted, there is a statistically significant increase in the number of special districts created. On average, an additional 1.2 special districts are likely be created when functional autonomy is granted to a city that is fiscally restricted. It is important to note this relationship only holds for urban counties and the results are less precise with larger confidence intervals.

These two results are consistent with the circumvention argument made above. When a city can satisfy the service demands of individuals and businesses (functional autonomy) and has its fiscal autonomy limited (a potentially binding TEL), potentially limiting the city's ability to satisfy the demands of individuals and businesses, we observe an increase in the creation of special districts. This suggests that individuals, businesses, cities, or a combination of the three are attempting to satisfy their demands for public services by turning to special districts. This is the exact result that Farmer (2010) finds for county governments at low levels of either restriction. However, the similarity in results diverge at higher levels of restrictions. Farmer finds that the combination of more restrictive levels of TELs and functional autonomy of counties leads to fewer special districts. We find evidence to the contrary. Farmer does not test this conditional relationship for municipal governments and this omission may explain some of differences between our two findings.

\footnotetext{
${ }^{9}$ This is later confirmed through graphical analysis, but we do not present such results. They are available upon request.
} 

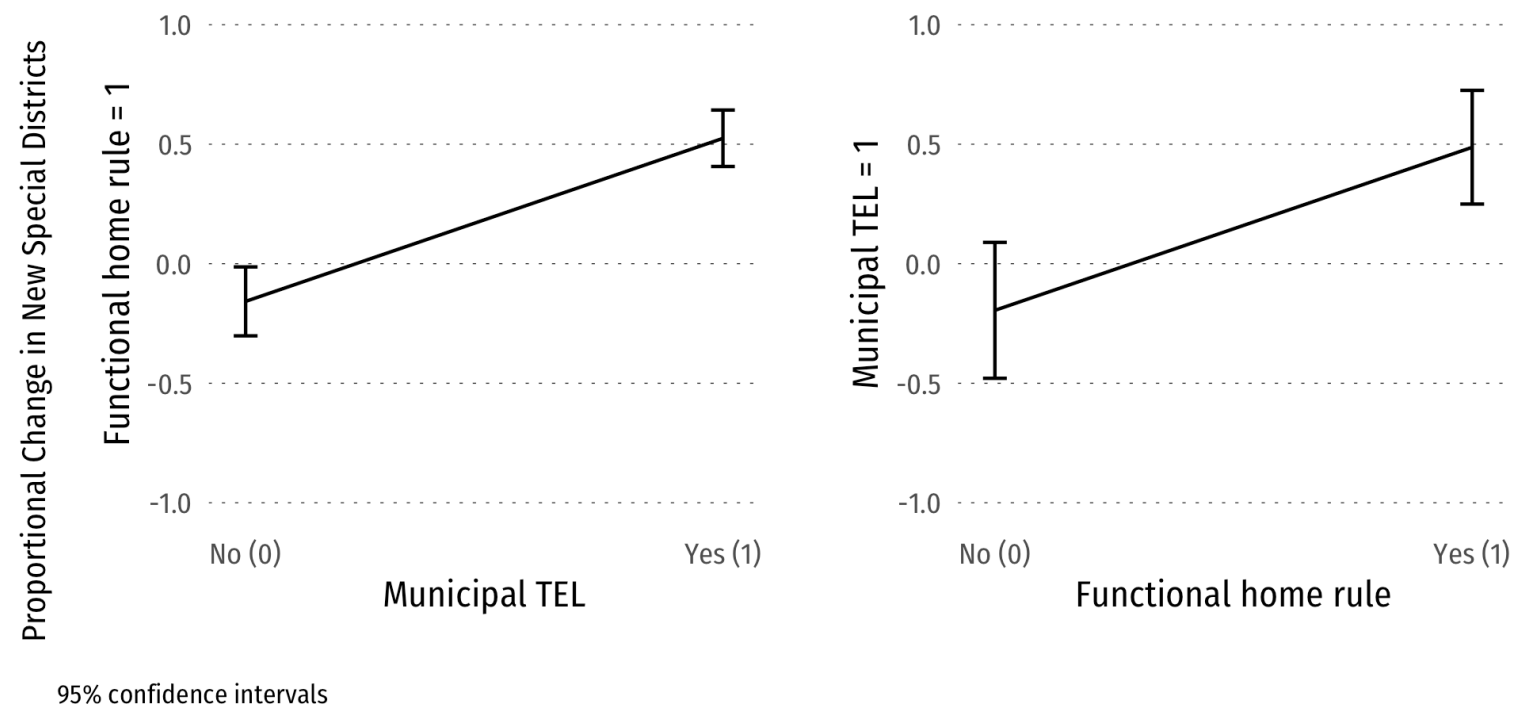

(a) Urban Counties
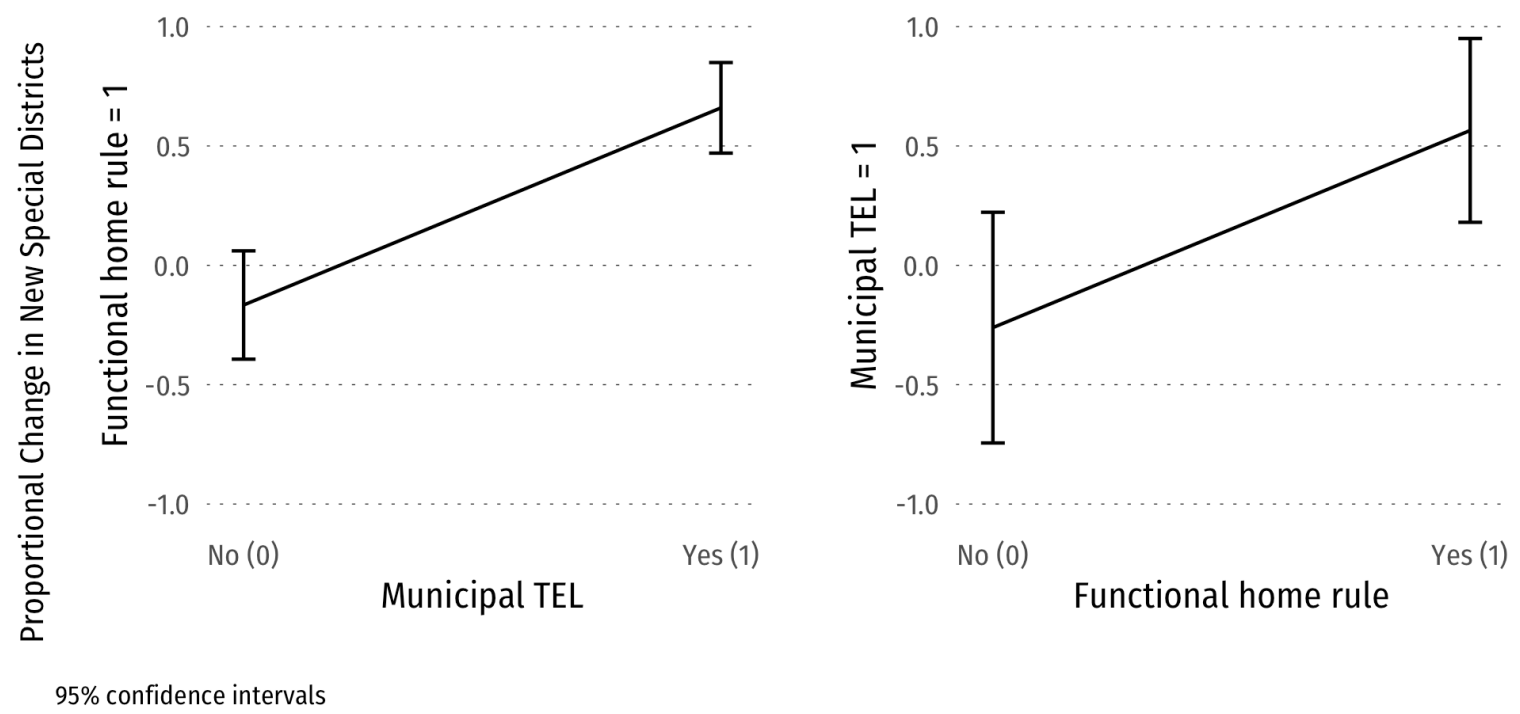

(b) MSAs

Figure 1: Predicted Effects of Functional Autonomy \& Fiscal Autonomy 


\section{Conclusions \& Policy Implications}

While the recent literature has focused on state changes in local autonomy as important precursors to special district formation, the exact nature of the relationship between autonomy and formation is unclear. Early literature answered this question with a direct relationship between changes in autonomy and special district formation or usage (Nelson 1990; McCabe 2000). More recently, the literature has turned to a contingent explanation of the relationship; positing that a combination of grants of autonomy (or lack thereof) is the most influential (Carr 2006; Farmer 2010; Carr and Farmer 2011). Even within this strain of the literature, there is not agreement about which combination of factors are the most important. A potential reason for this lack of agreement is the lack of long panels to capture changes in autonomy as well as control for time-invariant effects. The intent of this analysis was to examine this gap. Therefore, we examined the relationship between changes in local fiscal autonomy and the creation of special district governments in the United States. We find evidence of a conditional relationship between limitations of fiscal autonomy and functional autonomy of municipal governments and the creation of special districts. For those cities with functional autonomy, the introduction of a limit on their fiscal autonomy leads to the creation of new special districts. This relationship is consistent with the circumvention hypothesis outlined above. Under such a hypothesis, citizens and businesses prefer to receive demanded services from a general-purpose government but will seek to create a special district when those service demands are unable to be satisfied. Circumvention of limitations on fiscal autonomy is not the intended effect of TELs as envisioned by state legislatures. These findings speak directly to the efficacy or lack thereof of such limitations in curbing the growth of local governments. We find little evidence that restrictions on debt issuance leads to the creation of special districts. Similarly, we find little evidence of an independent effect of limitations of functional autonomy. These final two results are most similar to those found by Shi (2017) who finds little to no evidence debt limits or grants of home rule influence the number of special districts in a state.

This analysis provides a unique contribution in the special districts literature and the public choice literature more broadly. First, few analyses focus on special district creation (Bauroth 2015; Billings and Carroll 2012; Farmer 2010; McCabe 2000). Rather, they focus on the usage of special districts (Bowler and Donovan 2004; Carr 2006; Carr and Farmer 2011; Foster 1996; Frant 1997; Nelson 1990; Shi 2017). Second, few analyses utilize panel data ((Billings and Carroll 2012; Farmer 2010; McCabe 2000; Shi 2017) and among those that do, few utilize as many time periods as the analysis presented here. Finally, a county or metropolitan area level of aggregation is not uniformly agreed upon (Bauroth 2015; Billings and Carroll 2012; Carr and Farmer 2011; Farmer 2010; Nelson 1990). None of these contributions is unique on their own; however, the combination of focusing on special district creation, over a long panel, at the county level is novel in the literature. The combination allows for local demand conditions to be effectively controlled for while controlling for state-level time-invariant effects. Doing so makes the empirical test of changes in local autonomy on special district creation more effective than previously attempted.

This research speaks directly to the efficacy of state-imposed fiscal restrictions. While the goal of many of these limits is to stunt the growth of or reduce the size of general purpose local governments, our results suggest that the actual effect is to shift local government services from a limited form of government (cities) to an unlimited form of local government (special districts), thus creating greater fragmentation in most metropolitan areas. This effect is amplified when cities have functional autonomy. Combined with previous research, evidence suggests that TELs push local 
governments away from the property tax and toward user chargers (Shadbegian 1999) and push service provision away from general purpose local governments and toward special districts.

\section{References}

Advisory Commission on Intergovernmental Relations. 1981. Measuring Local Discretionary Authority. Washington, D.C.: Government Printing Office.

- . 1993. State Laws Governing Local Government Structure and Administration. Washington D.C.: Government Printing Office.

— . 1995. Tax and Expenditure Limitations on Local Governments. Bloomington, IN: Center for Urban Policy / the Environment, Indiana University.

Allison, Paul D. 2009. Fixed Effects Regression Models. Thousand Oaks, CA: SAGE Publications.

Allison, Paul D., and Richard P. Waterman. 2002. "Fixed Effects Negative Binomial Regression Models." Sociological Methodology 32 (1): 247-265.

Bauroth, Nicholas. 2015. “Hide In Plain Sight: The Uneven Proliferation of Special Districts Across the United States by Size and Function." Public Administration Quarterly 39 (2): 295-324.

Benton, J. Edwin. 2002a. Counties as Service Delivery Agents: Changing Expectations and Roles. Westport, CT: Praeger.

— . 2002b. "County service delivery: Does government structure matter?" Public Administration Review 62 (4): 471-479.

Berman, Evan M., and Jonathan P. West. 2012. "Public Values in Special Districts: A Survey of Managerial Commitment." Public Administration Review 72 (1): 43-54.

Berry, Christopher R. 2009. Imperfect Union: Representation and Taxation in Multilevel Governments. Cambridge: Cambridge University Press.

Billings, Stephen B., and Deborah A. Carroll. 2012. "Debrucing the Link Between Tax and Expenditure Limits and Special District Governments." Growth and Change 43 (2): 273-303.

Bollens, John C. 1957. Special District Governments in the United States. Berkeley and Los Angeles: University of California Press.

Bollens, Scott. 1986. "Examining the Link between State Policy and the Creation of Local Special Districts." State \& Local Government Review 18 (3): 117-124.

Bowler, Shaun, and Todd Donovan. 2004. "Evolution in state governance structures: Unintended consequences of state tax and expenditure limitations." Political Research Quarterly 57 (2): 189_ 196.

Brambor, Thomas, William Roberts Clark, and Matt Golder. 2006. "Understanding interaction models: Improving empirical analyses." Political Analysis 14 (1): 63-82.

Braumoeller, Bear F. 2004. "Hypothesis testing and multiplicative interaction terms." International Organization 58 (4): 807-820.

Bunch, Beverly S. 1991. "The Effect of Constitutional Debt Limits on State Government Use of Public Authorities." Public Choice 68 (1): 57-69. 
Burbridge, John B., Lonnie Magee, and A. Leslie Robb. 1988. "Alternative transformation to handle extreme values of the dependent variable." Journal of the American Statistical Association 83 (401): 123-127.

Burns, Nancy. 1994. The Formation of American Local Governments: Private Values in Public Institutions. New York, NY: Oxford University Press.

Cameron, Colin A., and Pravin K. Trivedi. 2005. Microeconometrics: Methods and Applications. New York, NY: Cambridge University Press.

Carr, Jered B. 2006. "Local Government Autonomy and State Reliance on Special District Governments: A Reassessment." Political Research Quarterly 59 (3): 481-492.

Carr, Jered B., and Jayce Farmer. 2011. "Contingent Effects of Municipal and County TELs on Special District Usage in the United States." Publius: The Journal of Federalism 41 (4): 709-733.

Epple, Dennis, and Chester Spatt. 1986. "State Restrictions on Local Debt: Their Role in Preventing Default." Journal of Public Economics 29 (2): 199-221.

Farmer, Jayce. 2010. "Factors Influencing Special Purpose Service Delivery among Counties." Public Performance \& Management Review 33 (4): 535-554.

Farnham, Paul G. 1985. "Re-examining local debt limits: A disaggregated analysis." Southern Economic Journal 51 (4): 1186-1201.

Fisher, Ronald C., and Robert W. Wassmer. 1998. "Economic Influences on the Structure of Local Government in US Metropolitan Areas." Journal of Urban Economics 43 (3): 444-471.

Foster, Kathryn A. 1996. "Specialization in Government: The Uneven Use of Special Districts in Metropolitan Areas." Urban Affairs Review 31 (3): 283-313.

— . 1997. The Political Economy of Special-Purpose Government. Washington D.C.: Georgetown University Press.

Frant, Howard. 1997. "Reconsidering the Determinants of Public Authority Use." Journal of Public Administration Research and Theory 7 (4): 571-590.

Frederickson, H. George. 1999. "The Repositioning of American Public Administration." PS: Political Science \& Politics 32 (4): 701-712.

Goodman, Christopher B. Forthcoming. "Usage of Specialized Service Delivery: Evidence from Contiguous Counties." Publius: The Journal of Federalism.

Goodman, Christopher B., and Suzanne M. Leland. 2012. "Cost shocks and their relationship to the creation, consolidation and dissolution of US local governments." Public Finance E Management 13 (2): 58-79.

Hausman, Jerry, Bronwyn H. Hall, and Zvi Griliches. 1984. "Econometric Models for Count Data with an Application to the Patents-R\&D Relationship." Econometrica 52 (4): 909-938.

Johnson, Norman L. 1949. "Systems of Frequency Curves Generated by Methods of Translation." Biometrika 36 (1/2): 149-176.

Joyce, Phillip G., and Daniel R. Mullins. 1991. "The Changing Fiscal Structure of State and Local Public Sector: The Impact of Tax and Expenditure Limitations." Public Administration Review 51 (3): 240-253. 
Krane, Dale, Platon N. Rigos, and Melvin B. Hill. 2001. Home Rule in America: A Fifty-State Handbook. Washington D.C.: CQ Press.

Leigland, James. 1990. "The Census Bureau's Role in Research on Special Districts: A Critique." Western Political Quarterly 43 (2): 367-380.

Leik, Robert K. 1966. “A Measure of Ordinal Consensus.” Pacific Sociological Review 9 (2): 85-90.

Lewis, Paul G. 2000. "The Durability of Local Government Structure: Evidence from California." State \& Local Government Review 32 (1): 34-48.

MacKinnon, James G., and Lonnie Magee. 1990. “Transforming the Dependent Variable in Regression Models." International Economic Review 31 (2): 315-339.

MacManus, Susan A. 1981. "Special District Governments: A Note on Their Use As Property Tax Relief Mechanisms in the 1970s." The Journal of Politics 43 (4): 1207-1214.

Martinez-Vasquez, Jorge, Mark Rider, and Mary Beth Walker. 1997. "Race and the Structure of School Districts in the United States." Journal of Urban Economics 41 (2): 281-300.

McCabe, Barbara C. 2000. "Special-District formation among the states." State $\mathcal{E}$ Local Government Review 32 (2): 121-131.

Menzel, Donald C., et al. 1992. "Setting a Research Agenda for the Study of the American County." Public Administration Review 52 (2): 173-182.

Mullins, Daniel R., and Phillip G. Joyce. 1996. "Tax and Expenditure Limitations and State and Local Fiscal Structure: An Empirical Assessment." Public Budgeting E Finance 16 (1): 75-101.

Mullins, Daniel R., and Bruce A. Wallin. 2004. "Tax and Expenditure Limitations: Introduction and Overview." Public Budgeting and Finance 24 (4): 2-15.

National Association of Home Builders. 2014. An Overview of Special Purpose and Taxing Districts.

Nelson, Michael A. 1990. "Decentralization of the Subnational Public Sector: An Empirical Analysis of the Determinants of Local Government Structure in Metropolitan Areas in the US." Southern Economic Journal 57 (2): 443-457.

Parks, Roger B., and Ronald J. Oakerson. 1989. "Metropolitan Organization and Governance: A Local Public Economy Approach." Urban Affairs Review 25 (1): 18-29.

Sbragia, Alberta M. 1996. Debt Wish: Entrepreneurial Cities, U.S. Federalism, and Economic Development. Pittsburgh: University of Pittsburgh Press.

Shadbegian, Ronald J. 1998. “Do Tax and Expenditure Limitations Affect Local Government Budgets? Evidence from Panel Data." Public Finance Review 26 (2): 118-136.

- . 1999. "The Effect of Tax and Expenditure Limitations on the Revenue Structure of Local Government, 1962-87." National Tax Journal 52 (2): 221-237.

Shi, Yu. 2017. "The Rise of Specialized Governance in American Federalism: Testing Links Between Local Government Autonomy and Formation of Special District Governments." Publius: The Journal of Federalism 47 (1): 99-130.

Sokolow, Alvin D. 1998. “The Changing Propery Tax and State-Local Relations." Publius: The Journal of Federalism 28 (1): 1650187.

Stephens, G. Ross, and Nelson Wikstrom. 1998. "Trends in special districts." State and Local Government Review 30 (2): 129-138. 
Tiebout, Charles M. 1956. "A Pure Theory of Local Expenditures." Journal of Political Economy 64 (5): 416-424.

U.S. Census Bureau. 2013. 2012 Census of Governments, Individual State Descriptions. Washington, D.C.: Government Printing Office.

\section{A Appendix}

\section{Alternate Estimation Strategy}

Before estimating equation 1 or 2 , a choice of estimator must be made. The simplest strategy would be to estimate equation 1 or 2 using OLS. The count of newly created special districts demonstrates a positive skew and the usual solution to such a problem is to transform the data using logs. However, as we observe the creation of new special districts rather than the usage of special districts, there are a non-trivial number of zeros in the data and this complicates the usage of log transformations. A technique must be chosen that considers the unique attributes of our data. Two potential estimators are available and there is some disagreement in the literature as to which is most appropriate: Poisson regression (McCabe, 2000) and negative binomial regression (Carr 2006; Farmer 2010; Carr and Farmer 2011; Shi 2017). The choice between estimator hinges whether the dependent variable is over-dispersed or not. Data are considered over dispersed when the conditional variance of the dependent variable is larger than the conditional mean (Cameron and Trivedi 2005). Poisson regression has a strict assumption that the conditional variance equals the conditional mean. Negative binomial regression does not make such an assumption and allows for a correction for over-dispersion. Testing for over-dispersion indicates that the strict assumption of Poisson regression does not hold (see significance test on Alpha in Table A.2. Therefore, we proceed with negative binomial regression.

Table A.1: Descriptive statistics

\begin{tabular}{|c|c|c|c|c|c|c|}
\hline \multirow[b]{2}{*}{ Variable } & \multirow[b]{2}{*}{ Source } & \multirow[b]{2}{*}{ Units } & \multicolumn{2}{|c|}{ Urban Counties } & \multicolumn{2}{|c|}{ MSAs } \\
\hline & & & Mean & St. Dev & Mean & St. Dev \\
\hline New special districts & COG & Count & 2.466 & 6.533 & 5.946 & 14.730 \\
\hline County TEL & Mullins & Indicator, 0 or 1 & 0.574 & 0.495 & 0.637 & 0.481 \\
\hline Municipal TEL & Mullins & Indicator, 0 or 1 & 0.538 & 0.499 & 0.600 & 0.490 \\
\hline County Debt Lim & ACIR & Indicator, 0 or 1 & 0.764 & 0.425 & 0.757 & 0.429 \\
\hline Municipal Debt Lim & ACIR & Indicator, 0 or 1 & 0.840 & 0.366 & 0.819 & 0.385 \\
\hline County FHM & Krane et al & Indicator, 0 or 1 & 0.436 & 0.496 & 0.451 & 0.498 \\
\hline Municipal FHM & Krane et al & Indicator, 0 or 1 & 0.746 & 0.435 & 0.753 & 0.431 \\
\hline Personal income, per capita & REIS & $\$ 1000$ per capita & 27.038 & 8.921 & 29.992 & 9.127 \\
\hline Population (1000s) & REIS & $1000 s$ & 248.226 & 529.870 & 610.851 & 1052.370 \\
\hline Jobs, per capita & REIS & Per capita & 0.398 & 0.137 & 0.444 & 0.092 \\
\hline Age Index & SEER & Index, 0 to 1 & 0.409 & 0.027 & 0.409 & 0.027 \\
\hline Race Index & SEER & Index, 0 to 1 & 0.151 & 0.130 & 0.171 & 0.114 \\
\hline Chg. in Cities & COG & Count & 0.100 & 0.611 & 0.245 & 1.083 \\
\hline No. of Counties & $\mathrm{COG}$ & Count & - & - & 2.137 & 1.945 \\
\hline Land Area (sqmi) & $\mathrm{COG}$ & Square miles & - & - & 2075.324 & 3129.592 \\
\hline
\end{tabular}


How the state-level fixed effects are utilized in the estimation of the model is also a concern. These fixed effects are included to control for unchanging and unmeasured features of states. The fixed effects negative binomial regression proposed by Hausman, Hall, and Griliches (1984) and implemented by the xtnbreg command in Stata is not a true fixed effects model. It is unable to effectively control for time-invariant effects as it utilizes the fixed effects to condition the overdispersion term rather than as regressors. Allison and Waterman (2002) suggest that negative binomial regression with a series of unconditional unit-specific dummy variables is the closest approximation of a true fixed effects model with no evidence of the incidental parameters problem. However, this estimation technique will generate standard errors with a downward bias (i.e. are too small). Standard errors can be adjusted upward by multiplying the standard errors by the square root of the ratio of the deviance term to its degrees of freedom. Allison (2009) suggests the vce(opg) option for the nbreg command in Stata is sufficient to eliminate this downward bias in the standard errors. We conduct an even more conservative hypothesis test by clustering standard errors on the state. This eliminates the downward bias in standard errors and corrects for any correlation between the errors terms within a given cluster (state). 
Table A.2: Fixed Effects Negative Binomial Regression Results

\begin{tabular}{|c|c|c|c|c|}
\hline \multirow[b]{2}{*}{ Variable } & \multicolumn{2}{|c|}{ Urban Counties } & \multicolumn{2}{|c|}{ MSAs } \\
\hline & (1) & (2) & (3) & (4) \\
\hline \multicolumn{5}{|l|}{ Fiscal $\mathcal{E}$ autonomy constraints } \\
\hline \multirow[t]{2}{*}{ Municipal TEL } & $0.6199^{*}$ & -0.2708 & 0.6569 & -0.4388 \\
\hline & $(0.292)$ & $(0.442)$ & $(0.356)$ & $(0.507)$ \\
\hline \multirow[t]{2}{*}{ Municipal functional home rule } & $0.5141^{*}$ & -0.1647 & $0.6474^{* *}$ & -0.3254 \\
\hline & $(0.200)$ & $(0.277)$ & $(0.251)$ & $(0.391)$ \\
\hline Municipal TEL $x$ & - & $1.1103^{* *}$ & - & $1.2671^{* *}$ \\
\hline Municipal functional home rule & & $(0.319)$ & & $(0.315)$ \\
\hline \multirow[t]{2}{*}{ Municipal debt limit } & -0.3066 & -0.2700 & -0.5651 & -0.5722 \\
\hline & $(0.346)$ & $(0.376)$ & $(0.424)$ & $(0.457)$ \\
\hline \multirow[t]{2}{*}{ County TEL } & -0.3048 & -0.1299 & -0.1665 & -0.0499 \\
\hline & $(0.294)$ & $(0.381)$ & $(0.353)$ & $(0.452)$ \\
\hline \multirow[t]{2}{*}{ County functional home rule } & -0.0427 & 0.0316 & 0.2445 & 0.2386 \\
\hline & $(0.220)$ & $(0.284)$ & $(0.235)$ & $(0.262)$ \\
\hline County TEL $x$ & - & -0.3164 & - & -0.1829 \\
\hline County functional home rule & & $(0.299)$ & & $(0.287)$ \\
\hline \multirow[t]{2}{*}{ County debt limit } & $0.3023^{*}$ & 0.2068 & 0.2074 & 0.1965 \\
\hline & $(0.154)$ & $(0.186)$ & $(0.326)$ & $(0.407)$ \\
\hline \multicolumn{5}{|l|}{ Controls } \\
\hline \multirow[t]{2}{*}{ Personal income, per capita } & $0.0161^{*}$ & $0.0157^{*}$ & $0.0395^{* *}$ & $0.0395^{* *}$ \\
\hline & $(0.007)$ & $(0.007)$ & $(0.010)$ & $(0.010)$ \\
\hline \multirow[t]{2}{*}{ Population (1000s) } & $0.0005^{* *}$ & $0.0005^{* *}$ & $0.0002^{* *}$ & $0.0002^{* *}$ \\
\hline & $(0.000)$ & $(0.000)$ & $(0.000)$ & $(0.000)$ \\
\hline \multirow[t]{2}{*}{ Jobs, per capita } & 0.5111 & 0.5238 & -0.9948 & -1.0343 \\
\hline & $(0.456)$ & $(0.454)$ & $(0.885)$ & $(0.874)$ \\
\hline \multirow[t]{2}{*}{ Age Index } & -3.7709 & -3.6614 & 0.3119 & 0.4996 \\
\hline & $(2.059)$ & $(2.091)$ & $(1.695)$ & $(1.705)$ \\
\hline \multirow[t]{2}{*}{ Race Index } & 0.6599 & 0.6479 & 0.0532 & 0.0991 \\
\hline & $(0.343)$ & $(0.339)$ & $(0.593)$ & $(0.575)$ \\
\hline \multirow[t]{2}{*}{ Chg Cities } & $0.1033^{* *}$ & $0.1025^{* *}$ & $0.0788^{*}$ & $0.0812^{*}$ \\
\hline & $(0.030)$ & $(0.034)$ & $(0.034)$ & $(0.038)$ \\
\hline \multirow[t]{2}{*}{ No. of Counties } & - & - & $0.2280^{* *}$ & $0.2285^{* *}$ \\
\hline & & & $(0.053)$ & $(0.054)$ \\
\hline \multirow[t]{2}{*}{ Land Area (sqmi) } & - & - & $0.0001^{*}$ & $0.0001^{*}$ \\
\hline & & & $(0.000)$ & $(0.000)$ \\
\hline \multirow[t]{2}{*}{ Constant } & 1.4114 & 1.4741 & $-0.2411^{*}$ & $-0.2558^{*}$ \\
\hline & $(0.103)$ & $(0.906)$ & $(0.826)$ & $(0.111)$ \\
\hline \multirow[t]{2}{*}{ Alpha } & $1.147^{* *}$ & $1.136^{* *}$ & $0.786^{* *}$ & $0.774^{* *}$ \\
\hline & $(0.118)$ & $(0.118)$ & $(0.087)$ & $(0.086)$ \\
\hline State FE & Yes & Yes & Yes & Yes \\
\hline Year FE & Yes & Yes & Yes & Yes \\
\hline Log-likelihood & $-11,180$ & $-11,161$ & $-5,456$ & $-5,445$ \\
\hline N (Observations) & 6,472 & 6,472 & 2,255 & 2,255 \\
\hline N (Clusters, states) & 47 & 47 & 47 & 47 \\
\hline
\end{tabular}

Cluster (state) robust standard errors in in parentheses; ${ }^{* *} p<0.01,{ }^{*} p<0.05$ 

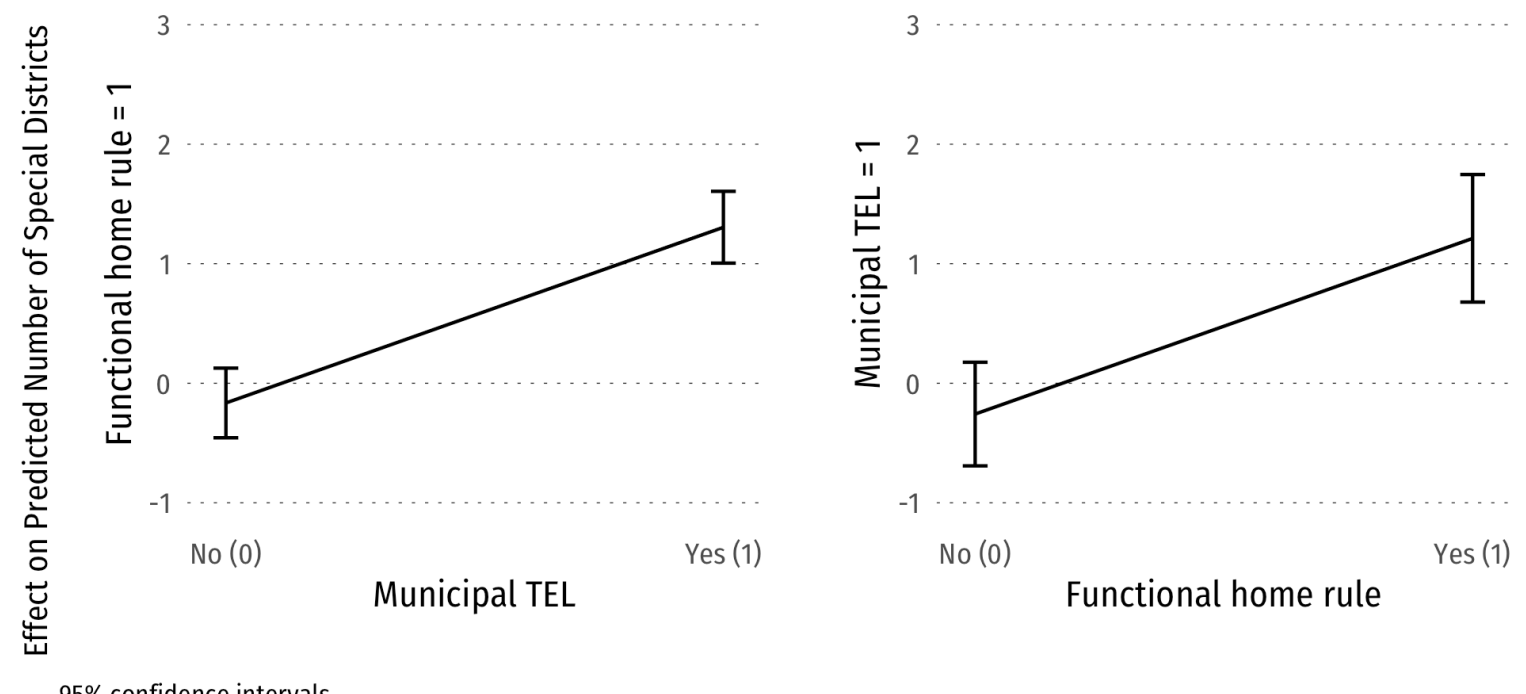

$95 \%$ confidence intervals

(a) Urban Counties
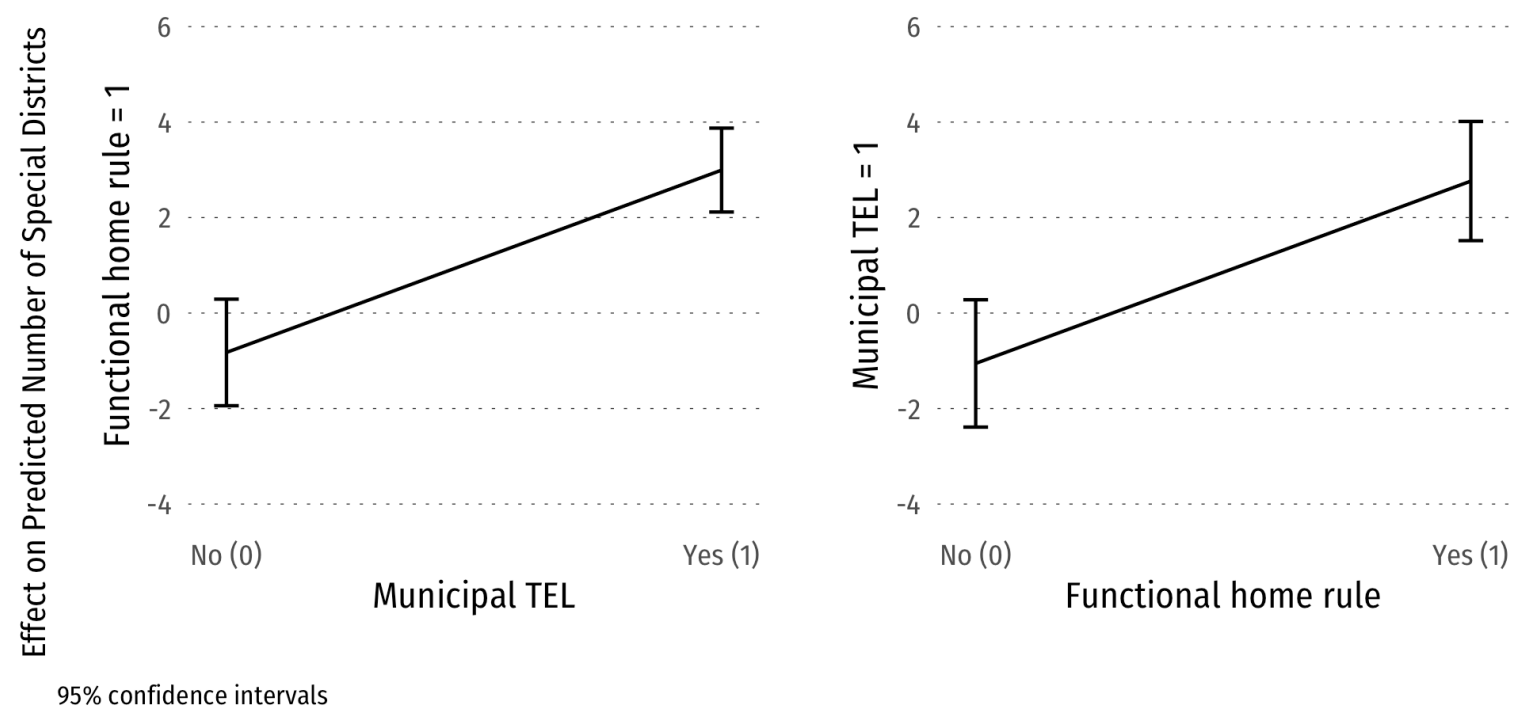

(b) MSAs

Figure A.1: Predicted Effects of Functional Autonomy \& Fiscal Autonomy (negative binomial) 